\title{
Article
}

\section{A preliminary study of the ectomycorrhizal fungi associated with introduced Eucalyptus in Kenya}

\author{
Garrett Kluthe $B^{1}$, Ben Hassine Ben Ali $M^{1}$, Nelsen DJ $^{1}$ and Stephenson SL $^{1}$ \\ ${ }^{1}$ Department of Biological Sciences, University of Arkansas, Fayetteville, Arkansas 72701
}

Garrett Kluthe B, Ben Hassine Ben Ali M, Nelsen DJ, Stephenson SL 2016 - A preliminary study of the ectomycorrhizal fungi associated with introduced Eucalyptus in Kenya. Mycosphere 7(1), 81-86, Doi 10.5943/mycosphere/7/1/8

\begin{abstract}
The assemblage of ectomycorrhizal fungi associated with introduced Eucalyptus in Kenya was characterized using molecular methods. DNA extracted from root-tips collected at 47 sites in the country yielded sequences of at least 21 taxa, with eight of these known to form ectomycorrhizal relationships with trees. Hydnangium carneum, a hypogenous fungus, and species of the agaric genus Laccaria appear to be the most common ectomycorrhizal associates of Eucalyptus. Other taxa recorded from the rhizosphere of Eucalyptus included two species of entomopathogenic fungi and a number of other species considered to be saprotrophic. As a general observation, based on the data obtained in the present study, the level of diversity of fungi associated with Eucalyptus appears to be relatively low.
\end{abstract}

Key words - Ectomycorrhizal fungi - Eucalyptus - DNA sequencing - Internal Transcribed Spacer - Kenya.

\section{Introduction}

Species of Eucalyptus L'Hér. (Myrtaceae), a large and diverse genus confined largely to Australia, have been introduced into other regions of the world because they are generally fastgrowing trees that produce wood that can be used for a variety of purposes. Eucalyptus is the most important planted tree in Africa and was first introduced to Kenya in the early 1900s (Brown 2003). Eucalyptus woodlands and plantations are most commonly found in the western highlands and Great Rift Valley regions of Kenya (Dessie 2011). These fertile regions are also the primary centers of agriculture for the country. Eucalyptus forms symbiotic relationships with ectomycorrhizal fungi. The successful growth of Eucalyptus trees is dependent upon this relationship, although the exact extent of this dependency varies from species to species (Ducousso et al. 2012). In Australia, a diverse assemblage of ectomycorrhizal fungi is associated with Eucalyptus, and many of the species involved appear to be endemic to that continent (Castellano \& Bougher 1994). In Kenya, the establishment of healthy Eucalyptus woodlots and plantations has required inoculating seedlings with the appropriate ectomycorrhizal fungi (Malajczuk et al. 1982). This can occur in one of two ways. First, the fungi can be introduced in the soil or leaf litter associated with the roots of the seedling. In such cases, these fungi are present in the soil of the nursery from which the seedling was obtained. Some of these fungi may well have been introduced to Kenya along with other exotic species of trees such as pines. Second, the fungi involved can be native species already 
present in the soil where the seedling is planted. However, there is some question as to whether or not many of the native fungi are even capable of forming ectomycorrhizal associations with Eucalyptus. Relatively little is known about the ectomycorrhizal fungi actually associated with Eucalyptus in Kenya because the appropriate studies have yet to be carried out. Ducousso et al. (2012) compiled data on the ectomycorrhizal fungi associated with Eucalyptus plantations in several different regions of the world, including Africa. They reported that the level of diversity of these fungi appears to be very low, with the widely distributed genus Pisolithus present and often dominant in most plantations. Their data were based on records of fruiting bodies collected in the field, and the authors pointed out that many of these appeared to be exceptional, with a particular species recorded only once or no more than a few times. The objective of this study was to add to the body of information available for the ectomycorrhizal associates of Eucalyptus in Kenya. Instead of recording species based on the occurrence of fruiting bodies, molecular methods were used to identify the fungi associated with root-tips collected from Eucalyptus trees at 47 different sites in Kenya (Fig. 1). These sites ranged from large commercial tree plantations to small woodlots on farms. With the exception of the study site in the Voi area, all the sites were in the Western Highlands and Great Rift Valley regions. The genus Eucalyptus (sensu lato) contains at least 700 species, and more than 150 of these have been introduced to Africa, either as pure species or as hybrids (Ducousso et al. 2012). Identification of a particular specimen of Eucalyptus to species is often problematic, even in its native habitats in Australia. However, the two most commonly encountered species in the study sites from which samples of root-tips were collected were $E$. grandis Hill ex Maiden (known as rose gum in Australia) and E. saligna Sm. (known as Sydney bluegum in Australia).

\section{Materials and Methods}

\section{Collecting root-tips}

In each study site, a single tree was arbitrarily selected after walking some distance into a Eucalyptus woodlot or plantation. At the base of each tree, a root was followed out for a distance of between 0.5 and $1.0 \mathrm{~m}$. Using a trowel, soil was removed from around the root and then finepointed forceps were used to collect the small root-tips from the larger root (Fig 1). These root-tips were placed in a $2 \mathrm{ml}$ microcentrifuge tube containing a 2.0\% CTAB (Cetyl Trimethyl Ammonium Bromide) solution. Later, all tubes containing root-tips were sent to the University of Arkansas for processing. In addition to the root-tips, three fruiting bodies of macrofungi were collected in close proximity to Eucalyptus trees in the various study sites. The very low number of such collections undoubtedly reflects the uniformly dry conditions that existed when the study sites were visited. The root-tip samples were collected during the May-June field seasons in 2013 and 2014 (Fig 2).

\section{Extraction of DNA}

As soon as they arrived at the University of Arkansas, all tubes were frozen at $-20 \mathrm{C}$ until the root-tips could be processed. First, root-tips were thawed and rinsed with distilled water to remove soil particles. Using a dissecting scope, individual colonized root-tips were selected and removed for subsequent extraction of DNA. Each individual colonized root-tip was placed in a separate microcentrifuge tube, and DNA was extracted using the Invisorb Spin Plant mini kit following the manufacturer's protocol. DNA also was extracted from the three fruiting bodies, and the same procedures outlined below were followed in order first to obtain a sequence and then to use the latter to identify the species involved.

\section{Amplification of DNA}

Extracted DNA was then amplified with a Bio Rad T100 Thermal Cycler (Bio Rad Inc., Hercules, CA) thermal cycler, using the primers ITS1 and ITS4 (White et al. 1990). PCR reactions were run with $12.5 \mu \mathrm{l}$ of GoTaq Green $2 \mathrm{X}$ master mix (Promega Madison, WI), $1.25 \mu 1$ of the forward primer, $1.25 \mu \mathrm{l}$ of the reverse primer, $1.0 \mu \mathrm{l}$ of DNA template, and $9.0 \mu \mathrm{l}$ of molecular 
grade water for a total reaction volume of $25 \mu 1$. PCR reactions were carried out with the following modifications to standard PCR conditions: Initial denaturation at $94^{\circ} \mathrm{C}$ for 3 minutes, followed by 36 cycles of $94^{\circ} \mathrm{C}$ denaturation for 1 minute, $54^{\circ} \mathrm{C}$ annealing for 45 seconds, and $72^{\circ} \mathrm{C}$ elongation for 1 minute, followed by a terminal elongation state at $72^{\circ} \mathrm{C}$ for 10 minutes.

\section{DNA sequencing and identification of fungi}

PCR products were verified using a $1 \%$ agarose gel and molecular standard to ensure products were of the expected size, approximately $600 \mathrm{bp}$, for the entire fungal ITS region (Op De Beeck et al. 2014). Products were then sent for Sanger Sequencing (Beckman Coulter Genomics, Danvers, MA). DNA sequences were returned in the form of chromatogram files with forward and reverse reads for each PCR product. DNA sequence reads were edited manually and contigs were assembled with SeqMan (Version 7.1.0) software program. Contiguous DNA sequences were then identified using the Basic Local Alignment Search Tool (BLAST) on the NCBI website (http://blast.ncbi.nlm.nih.gov/Blast.cgi). A threshold of 97\% identity or greater was used to assign species level identification to the sequences. The results were then verified using the UNITE database (http://www2.dpes.gu.se/project/unite/UNITE_intro.htm). In addition to the identification of fungal taxa, the sequence data obtained for each root-tip sample allowed the species of Eucalyptus from which the particular root-tip was collected to be identified.

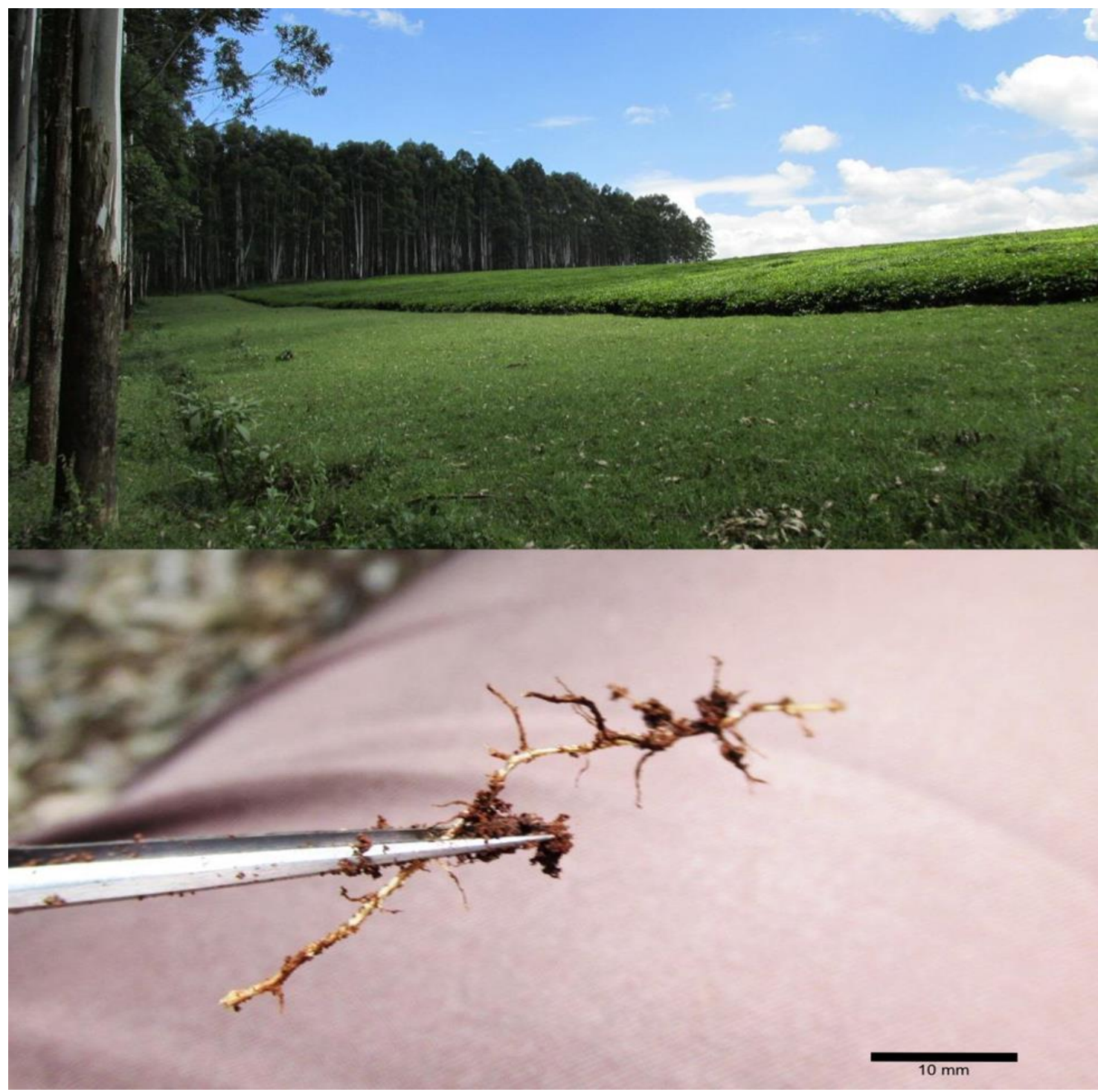

Fig. 1 - Eucalyptus woodlot in a tea plantation (upper image) and a collected root-tip from which fungal DNA was isolated (lower image). 


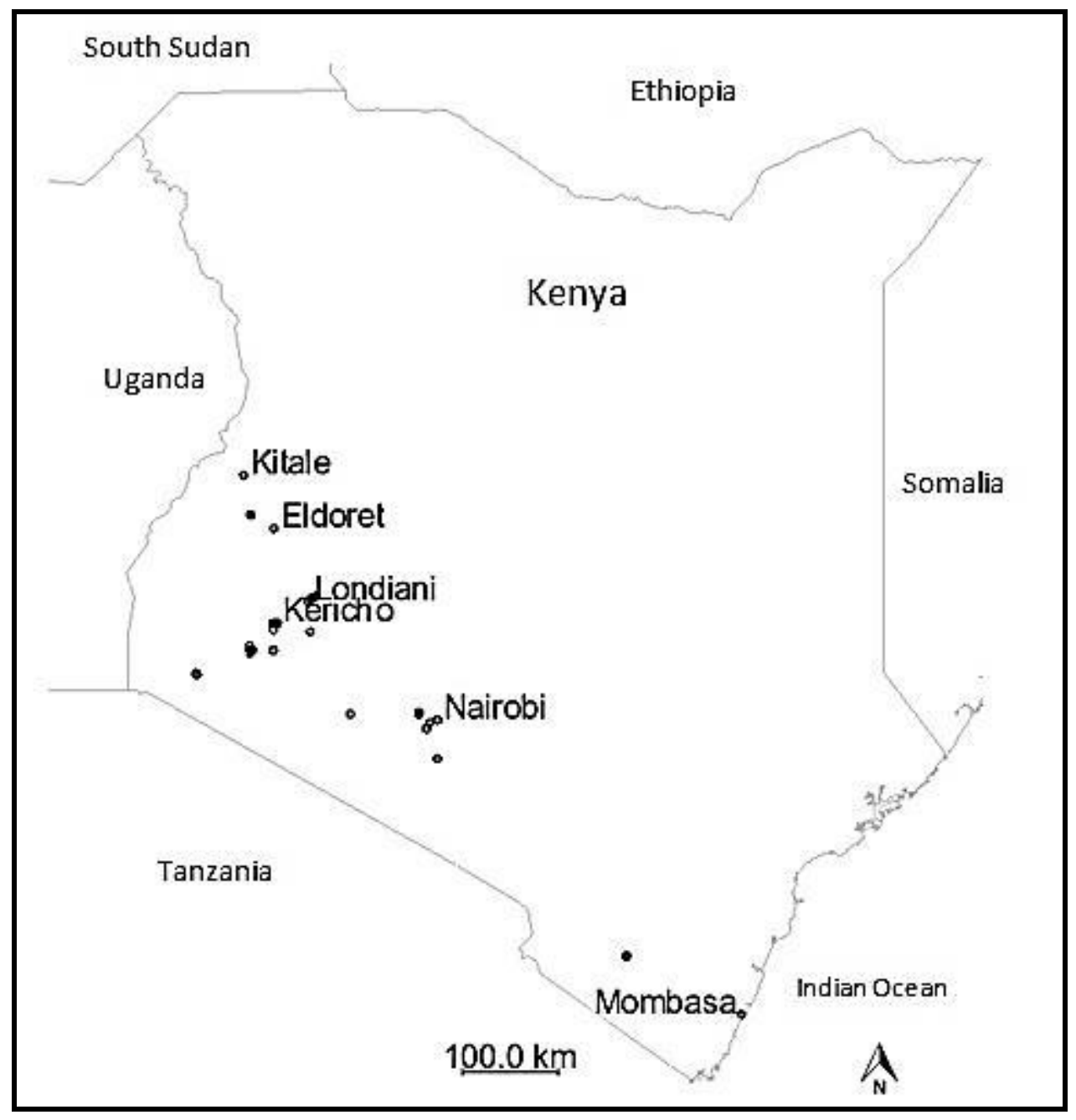

Fig. 2 - Localities in Kenya where Eucalyptus root-tips were collected in the present study.

\section{Results}

DNA was isolated from a total of 116 individual root-tips collected from trees in the 47 different study sites. Twenty-one taxa of fungi were identified from the sequences obtained from these root-tips, including eight ectomycorrhizal fungi and at least one representative from an order (Helotiales) and two classes (Leotiomycetes and Pezizomycetes) considered to be saprotrophic ${ }_{2}$ but which also contain at least a few species that are mycorrhizal (Table 1). The taxa recorded also included two entomopathogenic fungi commonly found in soil, one yeast (Meyerozyma guilliermondii) and representatives of three genera (Hydropus, Mycena, and Trechispora) known to be saprotrophic. All of these can be considered inhabitants of the rhizosphere in Eucalyptus plantations and woodlots, but they are not necessarily associated with the root systems of the Eucalyptus trees present.

The three fungi represented by fruiting bodies included one ectomycorrhizal species (Lactarius chichuensis W. F. Chiu) and two saprotrophic species (Agaricus subrutilescens [Kauffman] Hotson \& D. E. Stuntz and Psathyrella sp.). Based on the number of root-tips from which they were recorded, the ectomycorrhizal fungi most commonly associated with the Eucalyptus trees sampled in the present study are Hydnangium carneum, a hypogenous species that is likely to be overlooked in nature, and several species of Laccaria. The majority of the taxa identified from the sequences were associated with the two species of Eucalyptus (E. grandis and E. saligna) considered to be most common in the regions of Kenya from which root-tip samples were collected, but three other species were identified. These were E. maculata Hook. (= Corymbia maculata K.D. Kill \& L.A.S. Johnson), E. camaldulensis Dehnh. and E. globulus Labill. 
Table 1 Fungi identified from DNA extracted from root-tips of Eucalyptus at 47 study sites in Kenya

\begin{tabular}{|c|c|c|c|}
\hline Taxon & Group of fungi & Species of Eucalyptus & Ecology \\
\hline $\begin{array}{l}\text { Beauveria bassiana (Bals.-Criv.) } \\
\text { Vuill. }\end{array}$ & Ascomycota & E. grandis & Entomopathogenic \\
\hline $\begin{array}{l}\text { Descolea tenuipes (Setch.) Neville \& } \\
\quad \text { Poumarat }\end{array}$ & Basidiomycota & E. grandis & Ectomycorrhizal \\
\hline Descomyces sp. & Basidiomycota & E. grandis & Ectomycorrhizal \\
\hline Helotiales & Ascomycota & E. grandis & ?Saprotrophic \\
\hline Hydnangium carneum Wallr. & Basidiomycota & E. grandis & Ectomycorrhizal \\
\hline Hydropus sp. & Basidiomycota & E. grandis & Saprotrophic \\
\hline $\begin{array}{l}\text { Beauveria bassiana (Bals.-Criv.) } \\
\text { Vuill. }\end{array}$ & Ascomycota & E. maculate & Entomopathogenic \\
\hline Isaria amoenerosea Henn. & Ascomycota & E. maculate & Entomopathogenic \\
\hline Laccaria glabripes $\mathrm{McNabb}$ & Basidiomycota & E. grandis & Ectomycorrhizal \\
\hline Laccaria cf. lateritia Malenon & Basidiomycota & $\begin{array}{l}\text { E. grandis } \\
\text { E. globulus }\end{array}$ & Ectomycorrhizal \\
\hline Laccaria sp. & Basidiomycota & E. grandis & Ectomycorrhizal \\
\hline Leotiomycetes & Ascomycota & E. grandis & ?Saprotrophic \\
\hline $\begin{array}{l}\text { Meyerozyma guilliermondii (Wick.) } \\
\text { Kurtzman \& M. Suzuki }\end{array}$ & Ascomycota & E. grandis & Saprotrophic \\
\hline Mycena plumbea Sacc. & Basidiomycota & E. grandis & Saprotrophic \\
\hline Mycena pura (Pers.) Kumm. & Basidiomycota & E. camaldulensis & Saprotrophic \\
\hline Myxotrichum sp. & Ascomycota & E. grandis & Saprotrophic \\
\hline Pezizomycetes & Ascomycota & E. grandis & ?Saprotrophic \\
\hline $\begin{array}{l}\text { Pisolithus microcarpus (Cooke \& } \\
\text { Massee) G. Cunn. }\end{array}$ & Basidiomycota & E. camaldulensis & Ectomycorrhizal \\
\hline $\begin{array}{l}\text { Purpureocillium lilacinum (Thom) } \\
\text { Luangsa-ard Houbraken, Hywel- } \\
\text { Jones \& Samson }\end{array}$ & Ascomycota & E. grandis & Saprotrophic \\
\hline Scleroderma sinnamariense Mont. & Basidiomycota & E. camaldulensis & Saprotrophic \\
\hline $\begin{array}{l}\text { Tomentella parmastoana Suvi \& } \\
\text { Koljalg }\end{array}$ & Basidiomycota & E. globulus & Ectomycorrhizal \\
\hline Trechispora sp. & Basidiomycota & E. grandis & Saprotrophic \\
\hline
\end{tabular}

\section{Discussion}

The present study apparently represents the first effort to characterize the assemblages of ectomycorrhizal fungi associated with introduced Eucalyptus in Kenya with the use of molecular techniques, although such techniques have been widely used elsewhere in the world (Tedersoo et al. 2006, Smith et al. 2011, Lim and Berbee 2013). The results obtained certainly suggest that a high level of diversity does not exist for these fungi. This was not surprising, since diversity data based on fruiting bodies collected in Eucalyptus plantations apparently show a similar pattern (Ducousso et al. 2012).

Members of the genus Pisolithus has been reported previously as a common and often dominant ectomycorrhizal associates of Eucalyptus (Ducousso et al. 2012). However, only a single species (Pisolithus microcarpa [Cooke \& Massee] G. Cunn.) from just one study site was recorded in the present study. Interestingly, this species was recorded from the youngest Eucalyptus plantation included in the present study, with trees only three years old. This at least suggests that Pisolithus is among the first ectomycorrhizal associates to colonize the roots of Eucalyptus. However, this is based on exceedingly limited data. Scleroderma is another widely distributed ectomycorrhizal fungus in many regions of the world, but this genus was represented by only the single record of Scleroderma sinnamariense Mont. The most common gasteroid fungus was Hydnangium carneum Wallr, which was recorded from three different study sites. Members of the genus of Laccaria appear to be the ectomycorrhizal fungi most commonly associated with Eucalyptus in Kenya. This genus consists of an easily recognized group of white-spored agarics widely distributed in temperate regions of the world. 
Among the ectomycorrhizal fungi that were recorded, Descomyces is of particular interest. This taxon is limited to Austrasia and thus represents an example of an exotic fungi that was introduced (either intentionally or inadvertently) along with Eucalyptus.

The results reported herein clearly demonstrate that molecular identification of the fungi directly associated with the root-tips of Eucalyptus represents a viable approach to characterize the assemblage of species present in a plantation or woodlot where these trees occur. This approach can be used at any time of the year and does not require fruiting bodies to be collected. This is a major advantage, since the available of fruiting bodies suitable for study is unpredictable, especially under the xeric conditions that often exist in those regions of Kenya where Eucalyptus is found.

Although our data contribute to what is known about the ectomycorrhizal associates of Eucalyptus, the study itself was too limited in scope to be considered comprehensive. There is little doubt that additional studies are warranted.

\section{Acknowledgements}

Appreciation is extended to Phanuel O. Oballa, Jared Amwatta Mullah, Joram M. E. Mbinga and Willis A. Atie and several other individuals associated with the Kenya Forest Research Institute (KEFRI); George G. Ndiritu and the staff of the National Museums of Kenya; and Francis Onduso, research colleague and guide in Kenya. Special thanks are extended to the Finlay and Sotik tea plantations for allowing sampling to be carried out in their woodlots.

\section{References}

Brown K. 2003 - Trees, forests and communities: Some historiographical approaches to environmental history on Africa. Area 35 4, 343-356.

Castellano MA, Bougher NL. 1994 - Consideration of the taxonomy and biodiversity of Australian ectomycorrhizal fungi. Plant and Soil 159, 37-46.

Dessie G, Erkossa T. 2011 - Eucalyptus in East Africa Socio-economic and environmental issues. Forestry Department and Agriculture Organization of the United Nations. Working Paper FP46/E. May 2011.

Ducousso M, Duponnois R, Thoen D, Prin Y. 2012 - Diversity of ectomycorrhizal fungi associated with Eucalyptus in Africa and Madagascar. International Journal of Forestry Research. 2012. article ID 450715, 10 pages, 2012. doi:10.1155/2012/450715.

Lim S, Berbee ML. 2013 - Phylogenetic structure of ectomycorrhizal fungal communities of western hemlock changes with forest age and stand type. Mycorrhiza 23(6), 473-486.

Malajczuk N, Molina R, Trappe JM. 1982 - Ecotmycorrhiza formation in Eucalpytus. I. Pure culture synthesis, host specificity and mycorrhizal compatibility with Pinus radiata. The New Phytologist 91, 467-482.

Op De Beeck M, Lievens B, Busschaert P, Declerck S, Vangronsveld J, Colpaert JV. 2014 Comparison and Validation of Some ITS Primer Pairs Useful for Fungal Metabarcoding Studies. PLoS ONE, 9(6), e97629.

Smith ME, Henkel TW, Catherine AM, Fremier AK, Vilgalys R. 2011 - Ectomycorrhizal fungal diversity and community structure on three co-occurring leguminous canopy tree species in a Neotropical rainforest. New Phytologist 192(3), 699-712.

Tedersoo L, Suvi T, Larsson E, Kõljalg U. 2006 - Diversity and community structure of ectomycorrhizal fungi in a wooded meadow. Mycological research 110(6), 734-748.

White TJ, Bruns TD, Lee S, Taylor J. 1990 - Analysis of phylogenetic relationship by amplification and direct sequencing of ribosomal RNA genes. PCR Protocols: A Guide to Methods and Applications (Innis, M. A., Gelfand, D. H, Sninsky, J. J. \& White, T. J., (eds), pp. 315-322. Academic Press, New York. 